\title{
Comparative analysis of the influence of dry sauna bathing and whole-body cryostimulation on motor nerve excitability
}

\author{
Dawid Janczarzyk ${ }^{\mathbf{1}}$, Paweł Kurowski ${ }^{\mathbf{1}}$ \\ ${ }^{1}$ Doctoral School, University School of Physical Education in Krakow, Poland \\ Correspondence to: Dawid Janczarzyk, losos0@o2.pl \\ DOI: https://doi.org/10.5114/for.2021.106949
}

Received: 20.01.2021 Reviewed: 11.02.2021 Accepted: 11.02.2021

\begin{abstract}
Aims: The aim of this study was to determine and compare the effects of dry sauna bathing and whole-body cryostimulation on the motor excitability of the median nerve.

Material and methods: A group of 24 students from the State Higher Vocational School in Nowy Sacz, Poland were studied. The participants were divided into two groups: the first group underwent whole-body cryostimulation, while the second dry sauna therapy. Motor nerve excitability was tested by means of chronaximetry. The rheobase and chronaxie parameters were determined before and immediately after the procedures to check their influence on the examined parameters.
\end{abstract}

Key words chronaximetry, cryostimulation,

sauna

Results: Before the thermal stimuli were applied, there were no significant differences between the studied groups. The mean value of the median nerve rheobase after cryostimulation was significantly higher than after the dry sauna procedure. The changes in the chronaxie parameter, both before and after the treatments, were not statistically significant.

Conclusions: It has been proven that whole-body cryostimulation increases the threshold of motor nerve excitability in the case of the median nerve. The dry sauna showed the opposite tendency, causing a decrease in the excitability threshold. The results of the tested groups after the procedure were found to be significantly different. 


\section{Introduction}

As part of physical medicine, many agents can be used to induce changes in body homeostasis. Heat and cold therapies are largely popular, probably due to their availability. It may seem that heating and cooling stimuli should have opposite effects. However, many situations show that they can cause very similar reactions in the human organism. For example, the anti-oedema effect and improvement in blood supply are caused by the vasodilation of blood vessels supplying the area exposed to the stimulus. In the case of cold, however, vasodilation occurs only during the second phase of cooling (i.e., the reperfusion phase). In heat therapy, this effect occurs immediately. The analgesic, anti-inflammatory and muscle relaxation effects are other examples of outcomes that cold and heat treatments have in common. However, the effects induced by these two therapies are opposite in terms of nerve fibre excitability [1].

In this study, the influence of selected systemic heat and cold treatments on motor nerve excitability was addressed. We also describe the impact of heat and cold on the human body, including the selected physiological mechanisms involved therein.

\section{Aims}

The aim of this study was to determine and compare the effects of dry sauna bathing and whole-body cryostimulation on median nerve (MN) excitability.

\section{Material and methods}

\section{Study group}

The study group consisted of 24 physiotherapy students from the State Higher Vocational School in Nowy Sacz, Poland. The participants were healthy and without any contraindications to sauna and cryostimulation. All the subjects gave written consent to take part in the study and were randomly assigned to two groups: group A was exposed to cryostimulation, and group B underwent sauna therapy. It was ensured that the participants were well rested and not subjected to heavy physical effort in the 24 hours prior to the study. The subjects' heights and weights were measured (Tanita, Manchester, UK), and their body mass indexes (BMIs) were calculated.

Group A ( $\mathrm{n}=12,8$ women and 4 men) underwent a single session of whole-body cryostimulation. Group B ( $\mathrm{n}=12,8$ women and 4 men) participated in a single procedure of dry sauna bathing. The characteristics of the study groups are shown in Tables 1 and 2. Both groups were homogeneous in terms of baseline characteristics, with no statistically significant differences between them, as shown in Table 3.

Table 1. Characteristics of group $A(n=12)$.

\begin{tabular}{|c|c|c|c|}
\hline Statistical measures & Body height $(\mathbf{c m})$ & Body mass $(\mathbf{k g})$ & BMI $\left(\mathbf{k g} / \mathbf{m}^{2}\right)$ \\
\hline $\bar{x}$ & 173.5 & 69.32 & 22.87 \\
\hline $\mathrm{SD}$ & 6.65 & 11.5 & 2.09 \\
\hline
\end{tabular}

Legend: $\overline{\mathrm{x}}$ - mean, SD - standard deviation, BMI - body mass index. 
Table 2. Characteristics of group B $(n=12)$.

\begin{tabular}{|c|c|c|c|}
\hline Statistical measures & Body height (cm) & Body mass (kg) & BMI (kg/m $\left.{ }^{2}\right)$ \\
\hline $\bar{x}$ & 171.0 & 68.27 & 23.23 \\
\hline SD & 6.93 & 9.08 & 1.84 \\
\hline
\end{tabular}

Legend: $\overline{\mathrm{x}}$ - mean, SD - standard deviation, BMI - body mass index.

Table 2. Comparison of characteristics between groups A and B.

\begin{tabular}{|c|c|c|c|}
\hline Features & $\begin{array}{c}\text { Body height (cm) } \\
\overline{\mathbf{x}} \pm \text { SD }\end{array}$ & $\begin{array}{c}\text { Body mass (kg) } \\
\overline{\mathbf{x}} \pm \text { SD }\end{array}$ & $\begin{array}{c}\text { BMI (kg/m2) } \\
\overline{\mathbf{x}} \pm \text { SD }\end{array}$ \\
\hline Group A & $173.50 \pm 6.65$ & $69.32 \pm 11.50$ & $22.87 \pm 2.09$ \\
\hline Group B & $171.00 \pm 6.93$ & $68.27 \pm 9.08$ & $23.23 \pm 1.84$ \\
\hline $\mathrm{p}$ & 0.39 & 0.80 & 0.43 \\
\hline
\end{tabular}

Legend: $\overline{\mathrm{x}}$ - mean, SD - standard deviation, BMI - body mass index, $\mathrm{p}$ - level of significance $<0.05$.

\section{Rheobase and chronaxie}

The effects of the thermal treatments were evaluated using chronaximetry, a quantitative electrodiagnostic method [1]. The study was conducted in a specially adapted room. The subjects were in a comfortable sitting position with relaxed upper limb muscles. Measurements were taken with a BTL 5000 device (BTL Industries Inc., Greeneville, USA). The passive electrode (anode) was fixed using an elastic bandage laterally from the spine at the level of the scapula to the side of the tested upper limb (a $5 \mathrm{~cm} \times 7 \mathrm{~cm}$ flat carbon electrode was used). A moistened gauze pad was placed under the electrode and slightly protruded beyond the electrode area. The active electrode (cathode) consisted of a 1-cm-diameter spot electrode co- $^{-}$ vered with a moistened pad.

The excitability of the MN motor fibres was measured twice, just before the treatment and immediately after. The superficial part of the MN, usually located about $5 \mathrm{~cm}$ proximally from the elbow joint on the medial side of the arm, was localised by palpation. The location of the MN was confirmed by a first measurement to establish the rheobase, which was determined as the current intensity that induced a minimal flexor contraction of one of the 3 fingers supplied by the $\mathrm{MN}$. The muscle contraction was assessed visually using a stimulus duration of 1000 ms. Subsequently, the chronaxie was measured, which is the minimum duration of the stimulus-inducing muscle contraction. The applied current intensity was double the value of the previously achieved rheobase [1].

\section{Whole-body cryostimulation}

The procedure was carried out in accordance with the methodology found in the literature [2]. The preparation of the subjects was carefully checked before the study began. The subjects' clothing consisted of wooden clogs, warm 
knee-high socks, woollen gloves, a hat to cover the auricles, a surgical masque with gauze, and a bathing suit or shorts. The subjects had their skin wiped dry and were instructed on how to behave during the procedure. The cryostimulation took place in a cryochamber and lasted 2.5 minutes. First, the subjects stayed for 30 seconds in the atrium, where the temperature was $-50^{\circ} \mathrm{C}$; this stage allowed for adaptation. Subsequently, the participants entered the main chamber, where the temperature was $-110^{\circ} \mathrm{C}$, for 2 minutes. Throughout their stays in the atrium and main chamber, the subjects were asked to walk around and move their upper limbs. All participants had visual and verbal contact with the person coordinating the treatment procedure. After leaving the cryochamber, the subjects walked to a room at normal temperature where MN excitability was tested by assessing rheobase and chronaxie.

\section{Dry sauna bathing}

The treatment was carried out in accordance with the methodology described in the literature [1]. The procedure took place in a wooden sauna with three benches placed at heights of 45, 90 and 135 $\mathrm{cm}$. There was a timer, a thermometer and a hygrometer on the wall. Before the procedure, the subjects took a shower and then dried up. They subsequently covered with a cotton towel when they entered the sauna and sat on the highest bench. The temperature inside the sauna was about $100^{\circ} \mathrm{C}$ at the head level, gradually dropping to about $40^{\circ} \mathrm{C}$ at the floor level. The air humidity, as well as the temperature, varied depending on the height, ranging from $2 \%$ to $6 \%$ close to the ceiling and up to $60 \%$ close to the floor. The time spent in the sauna was 15 minutes, after which the subjects walked into a room at normal temperature. Afterwards, the rheobase and chronaxie of the MN motor fibres were tested analogously as after cryostimulation [3].

\section{Statistical analysis}

The collected results were statistically analysed using STATISTICA 13 (StatSoft, Dell Inc. Tulsa, USA). The basic descriptive statistics of the varia- bles tested are presented. Student's t-test for dependent samples was used to determine changes the in rheobase and chronaxie measurements before and after applying the treatments. The significance of the differences between the mean values of the independent variables was determined using the t-test for independent samples (groups $A$ and $B$ ). The level of statistical significance was set at $\mathrm{p}<0.05$.

\section{Results}

Before the treatment procedures, the rheobase values among all study participants were within the accepted normal range of 2-18 mA [4]. Moreover, before the treatments, there were no statistically significant differences between groups $\mathrm{A}$ and $\mathrm{B}$ in their mean values of motor rheobase for the MN. However, a significant difference was found in the mean value of MN motor rheobase between the groups after the application of thermotherapy. In the cryostimulation group, the mean value of rheobase was significantly higher $(p<0.05)$ than in the sauna group. The percentage difference in the mean rheobase between the groups was $29 \%$.

Differences in the mean rheobase values before and after cryostimulation were also observed. In group A, on average, higher rheobase values were noted after the procedure than before. Similarly, in the sauna treatment group, differences were observed before and after the treatment. In this case, the average rheobase value in group B appeared to be lower after the procedure than before. The results showing the mean rheobase values are presented in Table 4 and Figure 1. 
Table 4. Comparison of rheobase results between groups A (cryostimulation) and B (sauna), before and after procedure.

\begin{tabular}{|c|c|c|c|}
\hline Measurement & $\begin{array}{c}\text { Group A (n=12) } \\
\overline{\mathbf{x}} \pm \text { SD }\end{array}$ & $\begin{array}{c}\text { Group B (n=12) } \\
\overline{\mathbf{x}} \pm \text { SD }\end{array}$ & $\mathbf{p}$ \\
\hline $\begin{array}{c}\text { Rheobase before } \\
\text { the procedure (mA) }\end{array}$ & $2.02 \pm 0.54$ & $2.12 \pm 0.54$ & $* 0.68$ \\
\hline $\begin{array}{c}\text { Rheobase after } \\
\text { the procedure }(\mathrm{mA})\end{array}$ & $2.23 \pm 0.36$ & $1.58 \pm 0.37$ & $* 0.02$ \\
\hline
\end{tabular}

Legend: $\overline{\mathrm{x}}$ - mean, SD - standard deviation, $\mathrm{p}$ - level of significance $<0.05^{*}$

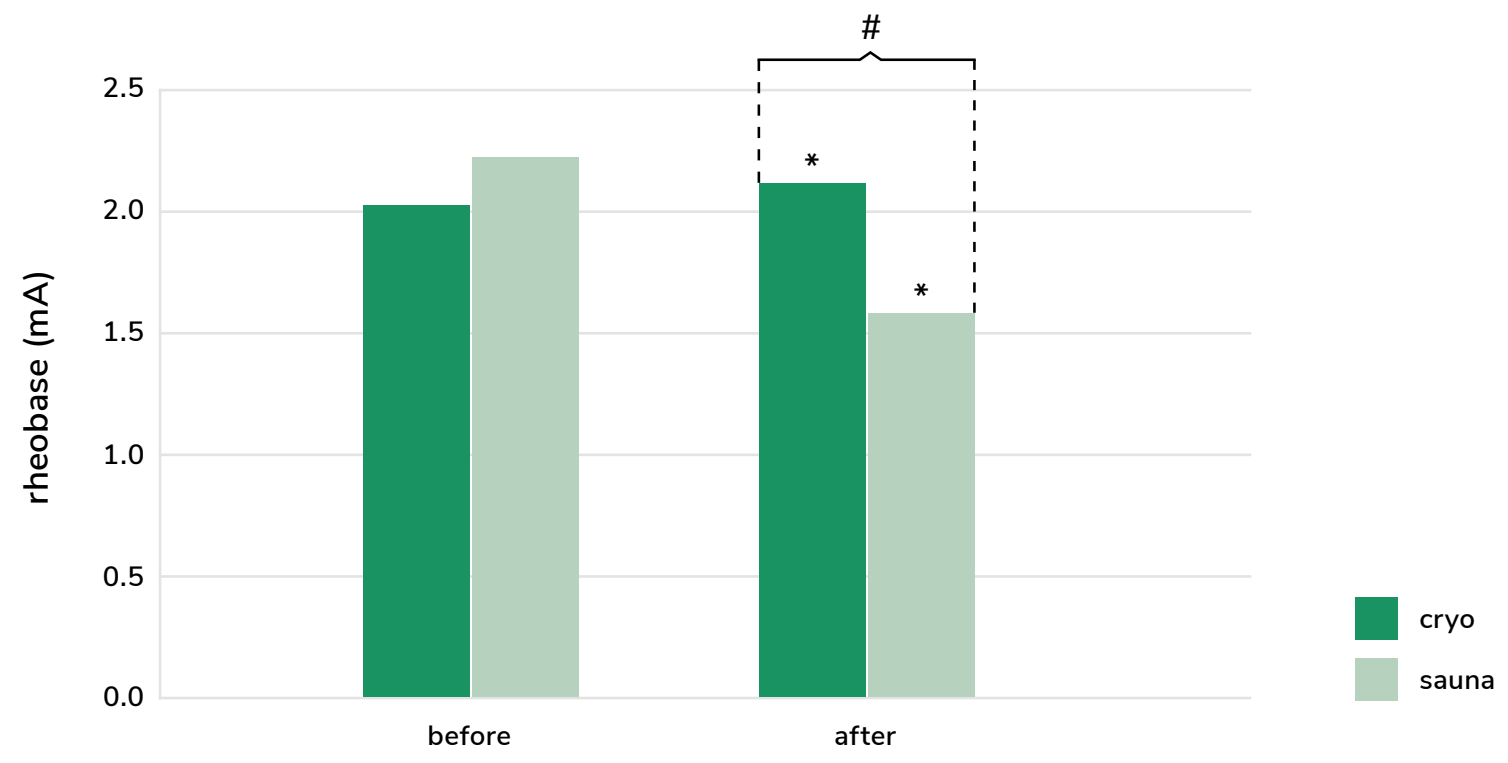

Figure 1. Differences between groups $A$ and $B$ in mean rheobase value before and after procedure

Notes: * Statistically significant differences observed before and after procedure, \#intergroup differences for $\mathrm{p}<0.05)$.

The established norm for the mean chronaxie is less than $1 \mathrm{~ms}$, and, as in the case of rheobase, the value was within the normal range for both groups [4]. There were no statistically significant $(p>0.05)$ differences in changes in the mean va- lue of chronaxie for either the intra-group or inter-group comparisons. The results showing the mean chronaxie values are presented in Table $\mathbf{5}$ and Figure 2. 
Table 5. Comparison of chronaxie results between groups A (cryostimulation) and B (sauna), before and after procedure.

\begin{tabular}{|c|c|c|c|}
\hline Measurement & $\begin{array}{c}\text { Group A (n=12) } \\
\overline{\mathbf{x}} \pm \text { SD }\end{array}$ & $\begin{array}{c}\text { Group B (n=12) } \\
\overline{\mathbf{x}} \pm \text { SD }\end{array}$ \\
\hline $\begin{array}{c}\text { Chronaxie before } \\
\text { the procedure (mA) }\end{array}$ & $0.37 \pm 0.13$ & $0.41 \pm 0.10$ & 0.42 \\
\hline $\begin{array}{c}\text { Chronaxie after } \\
\text { the procedure (mA) }\end{array}$ & $0.38 \pm 0.13$ & $0.37 \pm 0.15$ & 0.95 \\
\hline
\end{tabular}

Legend: $\overline{\mathrm{x}}$ - mean, SD - standard deviation, $\mathrm{p}$ - level of significance $<0.05^{*}$

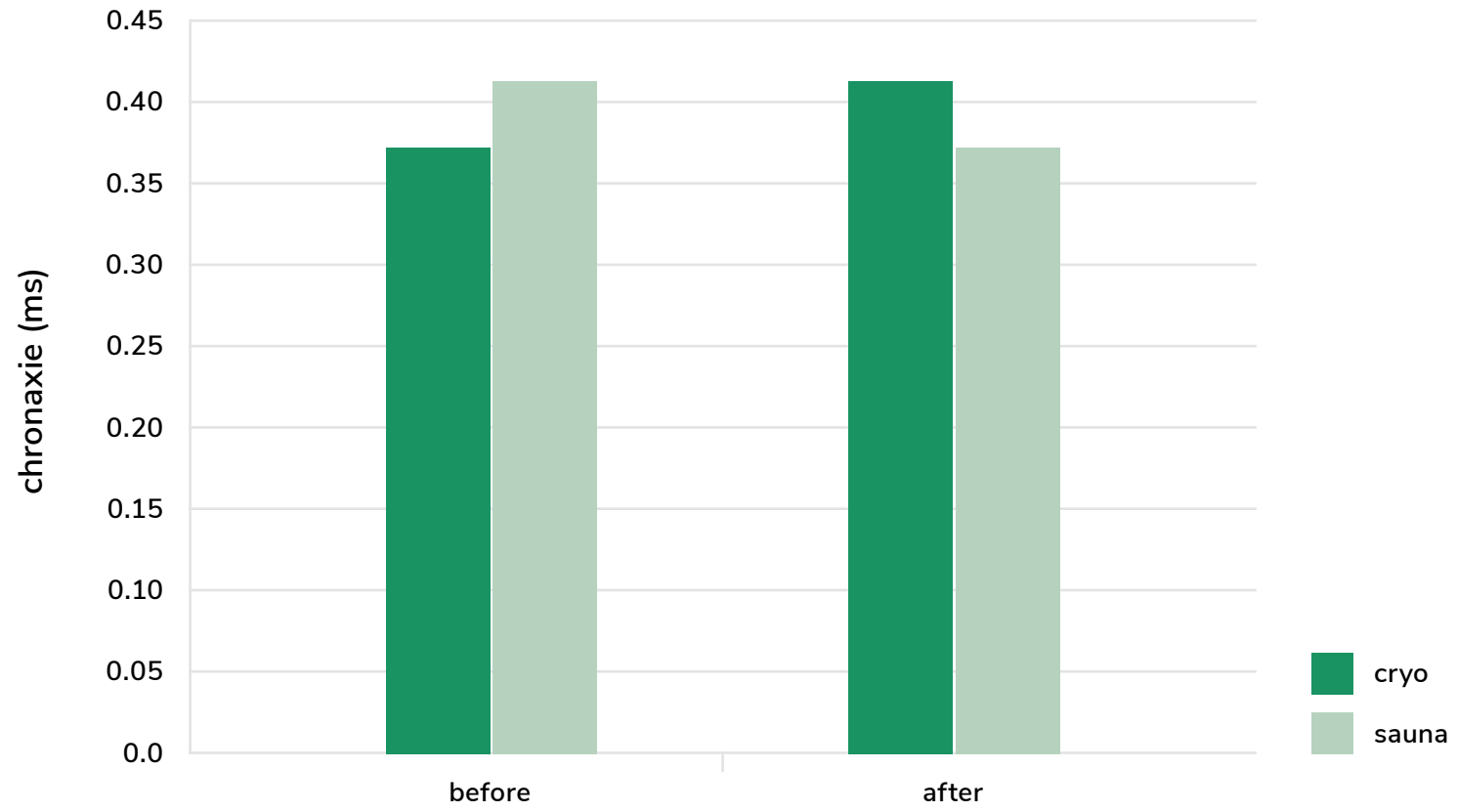

Figure 1. Differences between groups A and B in mean chronaxie value before and after procedure.

\section{Discussion}

The study revealed changes in the mean rheobase value, which may indicate a change in $\mathrm{MN}$ excitability. The group subjected to a single session of cryostimulation achieved an increased excitability threshold, while the group that underwent a single session of dry sauna experienced the opposite effect (decreased MN excitability). It was observed that the excitability threshold after cryostimulation was significantly higher compared to that obtained after a 15-minute dry sauna session. The rate of nerve conduction (chronaxie) did not show significant changes as a result of the examined thermal stimuli.

A brief review of the literature on the effects of cold therapy indicates the opposite direction of neurophysiological changes. This involves a 
decrease in conduction velocity and an increase in the nerve excitability threshold. In their study conducted on a group of 33 healthy people, Kamykowska et al. [5] demonstrated that a 20-minute application of cooling compresses at a temperature of $-10^{\circ} \mathrm{C}$ reduces neuromuscular excitability. Szczypior et al. [6] also showed that the application of local cryostimulation using gel compresses resulted in decreased nerve conduction in both the motor and sensory fibres of the nerves. Moreover, the researchers proved that the temperature reduction persisted longer in sensory fibres, which may indicate the fibres' higher sensitivity to low temperatures.

The effect of cold on the change in nerve conduction velocity was also investigated by Li [7], who showed that a decrease in body temperature below $15^{\circ} \mathrm{C}$ reduced the rate of neuromuscular conduction. On the other hand, a decrease to $4^{\circ} \mathrm{C}$ deactivated the neuromuscular synapse, completely blocking nerve conduction. Zagrobelny [8] reported that local cryostimulation with liquid nitrogen at a temperature of $-160^{\circ} \mathrm{C}$ reduces post-stroke spasticity. According to the author, the mechanism involved was a decrease in the rate of nerve conduction. Similar results correlating a decrease in body temperature with a reduction in spasticity were described by Stillwell [9].

The electrical impulse sent during chronaximetry testing must overcome the barriers of many tissues before it reaches the nerve structure [10]. The resistance of tissues depends on the degree of their hydration; Pietrzak [11] demonstrated that the higher the tissue hydration, the higher the tissue conductivity. The skin shows a high degree of resistance, surpassed only by that of bone tissue. It can therefore be concluded that the skin is the primary barrier that prevents electric current from penetrating deeper tissues, including the nerve structures. Furthermore, the skin's degree of hydration increases during increased skin blood flow, as blood plasma consists of $90 \%$ water [12]. Given that cryostimulation leads to superficial vasoconstriction and profound vasodilation $[13,14]$, according to the Dastre-Morat law, this treatment causes a decrease in blood flow thro- ugh the skin, which results in a lower degree of hydration [15].

The present study demonstrated an increased threshold of nerve excitability following a 2.5-minute whole-body cryostimulation session. The above mechanism, based on a decrease in skin hydration, may explain the increase in rheobase after the procedure, findings which are consistent with the literature $[1,8]$. Furthermore, it should be noted that the electrodiagnostic testing was performed immediately after leaving the cryochamber; due to this short time between the application of the stimulus and the measurement, the phenomenon called Lewis waves, which consists of a secondary vasodilation of the previously constricted vessels due to the cold, had not yet occurred [4].

No significant changes in the chronaxie parameter (nerve conduction velocity) were observed following cryotherapy. This result, as in the case of the rheobase parameter, differs from those of other studies, where, however, the treatment was applied only locally $[5,6,16]$. This can be explained by the fact that no additional movements of the treated limb are performed in the case of local cryostimulation, whereas in whole-body cryotherapy, patients perform alternate movements of the upper limbs.

According to Straburzynski and Straburzynska-Lupa [4], energy in the form of heat is produced during muscle contraction. The heat is transported through blood to the deeper located organs, ensuring their proper function. During local cryotherapy, patients are not asked to engage in any physical activity, which is associated with increased heat loss from the muscle. Numerous studies have confirmed a temperature decrease in locally cooled muscles. For example, Myrer et al. [17] compared cooling with ice cubes and cooling with cold water in a group of 32 subjects. They found that, in both cases, a 20-minute cooling period resulted in a significant temperature reduction of the gastrocnemius muscle. Moreover, Adamczyk et al. [18] showed that massage with ice cubes and cooling with cold water are characterised by a decrease in muscle tempe- 
rature, an effect confirmed by thermal imaging. Another study by Eldred et al. [19] showed a correlation between muscle temperature and motor fibre conduction velocity. The authors proved that a decrease in muscle temperature leads to a decrease in conduction velocity at the level of the neuromuscular junction. Therefore, there is a possibility that during the whole-body cryostimulation, the temperature of the muscles supplied by the $\mathrm{MN}$ increased during the upper limb movements, which prevented a decrease in the temperature-and, thus, in the conduction velocity-of the studied nerve.

It is recognised that all cold treatments have an analgesic effect $[1,2,4]$. The authors' results on whole-body cryostimulation indicate that this effect is not predominantly related to changes in the rate of nerve conduction. A potential analgesic mechanism may be linked to the secretion of beta-endorphins after the whole-body cryostimulation procedure [1]. According to Anaya-Terroba et al. [20], the analgesic effect of cold treatments is determined by a lowered level of pain mediators, such as bradykinin or histamine. Another gate control theory of pain by Melzack and Wall is based on the selectivity of stimulus permeability-the stimulus will first reach the grey matter of the posterior horn of the spinal cord [1]. In turn, Gregorowicz and Zagrobelny [21] proposed a different mechanism behind the analgesic effect of cold treatments depending on their type: systemic or local. In the case of local procedures, the main role is played by the decrease in nerve conduction velocity; however, in systemic treatments, it becomes secondary, which has been confirmed by the results obtained in the present study.

Heat treatment raises body temperature, which has been confirmed by various studies [22, 23]. Howells et al. have also shown that local hyperthermia significantly slows down nerve conduction among healthy individuals, which is explained by the impaired transport of potassium ions when tissue temperature rises [24]. Research conducted by Kamykowska et al. [5] proved that tissues which had been heated during short-wave diathermy were characterised by a decrease in nerve conduction. In the case of microwave diathermy, another method used by the researchers to increase the temperature, no effect similar to that of short-wave diathermy was obtained. Kovalchuck et al. [25] proved that better nerve conduction is observed at $35^{\circ} \mathrm{C}$ than at $20^{\circ} \mathrm{C}$. They also showed that motor fibres were more sensitive to an increase in body temperature and that this effect was longer than in sensory fibres. Similar findings can be found in Kiernan et al. [16].

The findings of the present study showed that a 15-minute dry sauna session was associated with a decrease in the mean rheobase value and very slight alterations in the mean chronaxie in the MN motor fibres. The improvement in blood supply to the skin due to the redirection of blood towards the superficial blood vessels may be an explanation for the above result. This effect is in agreement with Kasprzak and Mankowska [13], who reported that during sauna therapy, according to the Dastre-Morat law, there is a dilatation of the superficial vessels and also a significant secretion of sweat. Both mechanisms increase hydration, thus lower skin resistance, and consequently decrease rheobase (i.e., the excitability threshold).

The slight differences in nerve conductivity can be explained by the fact that, according to Pawlak et al. [22], sauna therapy increases the internal body temperature to $37.7^{\circ} \mathrm{C}$, and the body's efficient thermoregulatory mechanisms do not allow for large temperature changes within the nerve itself. Another study by Lowitzsch and De Jesus [26] proved that the temperature of the nerve itself has a key influence on conduction velocity, which increases by $5 \%$ with a temperature increase of $1^{\circ} \mathrm{C}$ (from $29^{\circ} \mathrm{C}$ to $38^{\circ} \mathrm{C}$ ).

In summary, the results of the present study show a significant difference in the mean value of the rheobase after cryostimulation and dry sauna. The significantly higher rheobase observed after cryostimulation indicates that it increased the threshold of nerve excitability. The opposite effect (of a decreased threshold) was observed 
in the case of sauna. The authors' thesis concerning the causes of the observed phenomenon is the degree of tissue hydration. Our study did not reveal any changes in the mean value of chronaxie after either cryostimulation or sauna therapy. Such findings indicate that none of these treatments led to changes in nerve conduction velocity.

\section{Study limitations}

The present study has some methodological limitations that need to be emphasised. First, the sample size was small, which indicates the need to repeat the study on a larger group. Second, there was no control group that received placebo therapy and we did not conduct a follow-up assessment, which could have given us insights into the long-term effects of the treatments. Additional technological options should also be considered by future researchers to increase the reliability of the results obtained (e.g., the use of electromyography). It would also be interesting to perform similar studies using local physical therapy procedures, which are now much more widely available.

\section{Conclusions}

This preliminary study has shown that a decrease in the excitability threshold of motor nerve fibres is probably not the principal mechanism responsible for the analgesic effect of systemic physical treatments. The analgesic effect of whole-body cryostimulation should be further studied. Potential underlying factors may include the reduction of pain mediators, beta-endorphin secretion or physical phenomenon such as the gate control theory of pain. Further observations on larger groups using objective research tools, such as electromyography or thermography, are needed.

\section{References}

1. Mika T. Kasprzak W. Fizykoterapia. Wydawnictwo Lekarskie PZWL. Warszawa 2013; str. 25-50.

2. Mikołajewska E. Fizykoterapia dla praktyków. Wydawnictwo Lekarskie PZWL. Warszawa 2011; str. 213-235.

3. Taradaj J. Sieroń A. Jarzębski M. Fizykoterapia w praktyce. Wydawnictwo Elamed. Katowice 2010; str. 7-38.

4. Straburzyński G. Straburzyńska-Lupa A. Medycyna fizykalna. Wydawnictwo Lekarskie PZWL. Warszawa 2000; str. 233-247, 332.

5. Kamykowska A, Polak A, Kucio C. et al. Badanie wpływu lokalnej termoterapii na pobudliwość nerwowo-mięśniową u osób zdrowych. Fizjoter Pol. 2011; 11 (2): 241-251.

6. Szczypior K, Polek A, Kubacki J. et al. Badanie wpływu krioterapii zmrożonymi okładami żelowymi i diatermii mikrofalowej na pobudliwość nerwu pośrodkowego, Fizykoterapia w praktyce. Wydawnictwo Elamed, 2010; 36-40.
7. Li CL. Effect of cooling on neuromuscular transmission in the rat. Am J Physiol. 1958; 194 (1): 200206.

8. Zagrobelny Z. Krioterapia miejscowa i ogólnoustrojowa. Elsevier Urban \& Partner, Wrocław 2003; str. 45-52.

9. Stillwell GK. Therapeutic heat and cold. Postgraduate Med. 1983; 73 (1): 70-76.

10. Lewitt A, Mądro E, Krupienicz A. Podstawy teoretyczne i zastosowanie analizy impedancji bioelektrycznej (BIA). Endokrynol Otył Zab Przem Mat. 2007; 3 (4): 79-84.

11. Pietrzak A, Wpływ pola elektormagnetycznego na rezystencję skóry ludzkiej - pomiary in vivo. Lett Oncol Sci. 2017; 14 (1): 10-15.

12. Traczyk W. Trzebski A. Fizjologia człowieka z elementami fizjologii stosowanej i klinicznej. Wydawnictwo Lekarskie PZWL. Warszawa 2015; str. 395398. 
13. Kasprzak W. Mańkowska A. Fizykoterapia, medycyna uzdrowiskowa i SPA. Wydawnictwo Lekarskie PZWL. Warszawa 2010; str. 8-22.

14. Gieremek K. Dec L. Zmęczenie i regeneracja sił, odnowa biologiczna. Has-Med. Bielsko-Biała 2000; str. 88-90.

15. Hubber J, Mechan D. Physiology for healthcare students. Churchill Livingstone, 1987. Kierman M, Cikurel K, Bostock H. Effects of temperature on the excitability properties of human motor axons. Brain 2001; 124 (4): 816-825.

16. Myrer JW, Measom G, Fellingham GW. Temperature changes in the human leg during and after two methods of cryotherapy. J Athl Train. 1998; 33 (1): 25-29.

17. Adamczyk J, Kraskowska I, Boguszewski D, Reaburn $P$. The use of thermal imaging to assess the effectivness of ice massage and cold-water immersion as methods for supporting post-excersise recovery. J Therm Biol. 2016; 60: 20-25

18. Eldred E, Lindsley D.F, Buchwald J.S. The effect of cooling on mammalian muscle spindles. Exp Neur. 1960; 2 (2): 144-157.

19. Anaya-Terroba L, Arroyo-Morales M, Fernández-de-las-Peñas, Diáz-Rodriĝez, Cleland JA. Effects of ice-massage on pressure pain thresholds and electromyography activity postexcersise: A randomized controlled crossover study. J Manipulative Physiol Ther. 2010; 33 (3): 212-219.
20. Gregorowicz H, Zagrobelny Z. Krioterapia ogólnoustrojowa. Wskazania

21. i przeciwwskazania, przebieg zabiegu i jego skutki fizjologiczne i kliniczne. Acta Bio-Opt Inform Med. 1998; 4 (3): 119-131.

22. Pawlak J, Zalewski P, Jacek J. et al. Zmiany temperatury głębokiej ciała po zabiegu sauny suchej osób zdrowych. Med Biol Sci. 2012; 26 (2): 111-114.

23. Leppäluoto J. Human thermoregulation in sauna. Ann Clin Res 1988; 20(4): 240-243.

24. Howells J, Czesnik D, Trevillion L. et al. Excitability and the safety margin in human axons during hyperthermia. J Physiol. 2013; 591 (12): 3063-3080.

25. Kovalchuk MO, Franssen H, Van Schelven LJ. et al. Comparing excitability at $37^{\circ} \mathrm{C}$ versus at $20^{\circ} \mathrm{C}$ : Differences between motor and sensory axons. Muscle Nerve. 2018; 57 (4): 574-580.

26. Lowitzsch K, Hopf HC, Galland J. Changes of sensory conduction velocity and refractory periods with decreasing tissue temperature in man. J Neurol. 1977; 216 (3): 181-188. 